\title{
Genetic Variations in Two Casein Genes Among Maghrabi Camels Reared in Egypt
}

\author{
Othman E. Othman $^{1 *}$, Amira M. Nowier ${ }^{2}$ and Medhat E. El-Denary ${ }^{3}$ \\ ${ }^{1}$ Cell Biology Department, National Research Centre, Dokki, Egypt. \\ ${ }^{2}$ Biotechnology Research Department, Animal Production Research Institute, Dokki, Egypt. \\ ${ }^{3}$ Genetic Department, Agriculture Faculty, Tanta University, Tanta, Egypt.
}

http://dx.doi.org/10.13005/bbra/2057

(Received: 23 January 2016; accepted: 19 March 2016)

\begin{abstract}
Camels play an important socio-economic role within the pastoral and agricultural system in the dry and semidry zones of Asia and African where they are dual purpose animals (meat and milk). In spite of the effective role of casein genes with their polymorphisms on quantitative traits and technological properties of milk, the studies on genetic polymorphism of camel milk genes are limited. This work aimed to identify the genetic polymorphisms and SNPs of two casein genes in Maghrabi camel breed in Egypt. The amplified fragments at $488-\mathrm{bp}$ of $\kappa$-CN gene were digested with AluI endonuclease. The results showed the presence of three genotypes; CC (12\%), TT (48\%) CT $(40 \%)$. The sequence analysis of two detected alleles declared the presence of a SNP $(\mathrm{C} \rightarrow \mathrm{T})$ at position 121 in amplified fragments. The nucleotide sequences of $\mathrm{k}$-CN alleles $C$ and $T$ were submitted to GenBank with accession numbers; KU055605 and KU055606, respectively. The primers used in this study amplified 942-bp fragments of ás1-casein gene. The results of $S m I I$ digestion did not showed any restriction site whereas the digestion with $A l u I$ endonuclease revealed the presence of two restriction sites $\mathrm{AG}^{\wedge} \mathrm{CT}$ at positions $68 \wedge 69$ and $63 \wedge^{\wedge} 632$ in amplified fragments. The nucleotide sequence of monomorphic as1-casein gene was submitted to GenBank with accession number KU145820.In conclusion, the genetic characterization of genes associated with milk yield and composition in camel is considered an essential step towards its genetic improvement through the selection of superior animals depending on the favorable alleles and genotypes; marker assisted selection (MAS).
\end{abstract}

Keywords: Genetic polymorphism, SNP, Maghrabi camel, к-casein gene, as1-casein gene.

A great interest has been directed to camels in the world; the camel is a very important animal in the arid and semi-arid regions. The survival of millions of human being is dependent on the camel in such areas for meat, milk and hair production and still an important mean of drought and transportation for large sectors of pastoral societies (El-Sawalhy et al., 1996). In spite of camel's considerable contribution to food security in semi dry and dry zones, and its being a major

\footnotetext{
* To whom all correspondence should be addressed. Fax: 20233370931

E-mail: othmanmah@yahoo.com
}

component of the agro-pastoral systems in vast pastoral areas in Africa and Asia, little is known about its production potential and systems compared to other domestic animals. However, most previous research conducted on camels was oriented towards diseases, reproductive physiology and characterization (Mehari et al., 2007).

In Egypt, camels are important animals because they are dual purpose animals (meat and milk production). In the Nile Valley and Delta, they are mainly raised for meat production and some agricultural labors. In the desert, they are raised equally for meat and milk production, some labors 
and transport. On the other hands, some breeders raise them for camel racing. It was reported that many camel breeds are reared in Egypt, but the main camel breeds are Maghrabi (a dual purpose animal), however, Falahy, Sudany and Mowaled (meat type animal) (Mahran, 2004).

Recently, genetic polymorphisms at candidate genes affecting economic traits have stimulated substantial research interest because of their impending utilization as an aid to genetic selection and to demarcate evolutionary relationships in different livestock breeds (Sodhi et al., 2007). Association of several polymorphic sites (SNPs) in different candidate genes with economic traits has been much investigated in different animal species. Studies on characterization of candidate genes and their polymorphism association with animal performance in camels are meager compared with other livestock; cattle (Lucy et al., 1991; Schlee et al., 1994; Ge et al., 2003), sheep (Wallis et al., 1998; Bastos et al., 2001) and goats (Wallis et al., 1998; Gupta et al., 2007).

The casein fraction of ruminant milk proteins consists of four caseins, namely $\alpha$ s1, $\alpha s 2, \beta$ and $\kappa-$ casein. These four caseins are the main components (76-86\%) of total milk protein (Swaisgood, 1992). The relative amounts of these four casein fractions affect the physicochemical, nutritional and technological properties of ruminant milks (Ramunno et al., 2000). The casein proteins include three main specific proteins which are the calcium-sensitive ( $\alpha$ s1-, $\alpha$ s2- and $\beta$-caseins) that coalesce with $\kappa$-casein, calcium and phosphate to form micelles. These casein proteins encoded by four clustered genes in a $250-k b$ genomic DNA fragment; $\alpha$ s1 is very close to $\beta$ followed by as 2 and $\kappa$-caseins (Provot et al., 1995).

Despite of the important role of casein genes and their effects on quantitative traits and technological properties of milk, few studies were focused on the genetic characterization of casein genes in camels comparing with other in ruminants. The present study aimed to identify the genetic variations (polymorphisms) in two casein genes; $\kappa$ - and $\alpha$ s1-casein genes in Maghrabi camel breed reared in Egypt using PCR-RFLP and nucleotide sequence analysis.

\section{MATERIALSAND METHODS}

\section{Animals and genomic DNA extraction}

The blood samples used in this study were collected from 50 Maghrabi camel females belonging to different farms; the camel production station in Marsa Matrouh (Animal Production Institute, 25 samples) and three private farms in West Desert of Egypt (25 samples).Genomic DNA was extracted from the whole blood according to the method described by Miller et al. (1988) with minor modifications. Briefly, blood samples were mixed with cold $2 \mathrm{x}$ sucrose-triton and centrifuged at $5000 \mathrm{rpm}$ for $15 \mathrm{~min}$ at $4^{\circ} \mathrm{C}$. The nuclear pellet was suspended in lysis buffer, sodium dodecyl sulfate and proteinase $\mathrm{K}$ and incubated overnight in a shaking water bath at $37^{\circ} \mathrm{C}$. Nucleic acids were extracted with saturated $\mathrm{NaCl}$ solution. The DNA was picked up and washed in $70 \%$ ethanol. The DNA was dissolved in $1 x$ TE buffer. DNA concentration was determined, using NanoDrop 1000 (Thermo Scientific Spectrophotometer) and then diluted to the working concentration of 50 $\mathrm{ng} / \mu \mathrm{l}$ which is suitable for polymerase chain reaction.

\section{Polymerase chain reaction:}

A PCR cocktail consisted of $1.0 \mu \mathrm{M}$ of upper and lower primer specific for each tested gene, $0.2 \mathrm{mM}$ dNTPs, 10x PCR reaction buffer and1.25 units of Taq polymerase (Fermentas). The cocktail was aliquot into PCR tubes with $100 \mathrm{ng}$ of camel DNA. The reaction was run according to the optimum condition specific for each primer (Table $1)$. The PCR products were subjected to electrophoresis on $2 \%$ agarose gel stained with ethidium bromide to test the amplification success.

\section{Restriction fragment length polymorphism (RFLP)}

The PCR products for each tested genes were digested with AluI and SmlI restriction enzymes. Ten $\mu$ l of PCR product were digested with $1 \mu$ l of FastDigest restriction enzyme for 15 min at the optimum temperature for maximum activity of each restriction enzyme. Gels were visualized under UV light and documented in FX Molecular Imager apparatus (BIO-RAD). Molecular size of the digested fragments were measured by analyzing gel images with Gel Analyzer software package version 2010a (freeware) with 100 bp DNA ladder (Larova GmbH-Germany) as 
DNA size marker.

\section{Sequence Analysis}

The PCR products-representatives for each detected genotype of each tested gene - were purified and sequenced by Macrogen Incorporation (Seoul, Korea). Sequence analysis and alignment were carried out using ClustalW2 to identify each single nucleotide substitution between different detected genotypes. Results of endouclease restriction were carried out using FastPCR. The nucleotide sequence of each genotype for camel $\kappa$-casein and $\alpha$ s1-casein genes were submitted to GenBank (NCBI, BankIt).

\section{RESULTSAND DISCUSSION}

Camels have an important role as meat and milk sources for many humans in different countries. The camel populations in Somalia and Sudan constitute a half of world camel populations (Pauciullo et al., 2013). The camel population in Egypt was estimated to be 120.000 headsand its ecotypes serve numerous functions in their respective production systems (e.g. milk and meat production, racing, riding and packing) and are bred and selected for sustainable performance (Mahran, 2004).

Table 1. The sequences and information of primers used in this study

\begin{tabular}{|c|c|c|c|c|c|}
\hline Gene & Primer sequence $52 \longrightarrow 32$ & $\begin{array}{l}\text { PCRConditions } \\
\text { (35 cycles) }\end{array}$ & $\begin{array}{c}\text { PCR } \\
\text { product } \\
\text { size }\end{array}$ & $\begin{array}{c}\text { Restriction } \\
\text { enzyme } \\
\text { used }\end{array}$ & References \\
\hline$\kappa$-casein & $\begin{array}{l}\text { CAC AAA GAT GAC TCT GCT ATC G } \\
\text { GCC CTC CAC ATA TGT CTG }\end{array}$ & $\begin{array}{l}94^{\circ} \mathrm{C} 1 \mathrm{~min} \\
56^{\circ} \mathrm{C} 1 \mathrm{~min} \\
72^{\circ} \mathrm{C} 2 \mathrm{~min}\end{array}$ & 488-bp & $\begin{array}{l}\text { AluI } \\
\text { SmlI }\end{array}$ & $\begin{array}{l}\text { Pauciullo } \\
\text { et al.(2013) }\end{array}$ \\
\hline as1-casein & $\begin{array}{l}\text { TGA ACC AGA CAG CAT AGA G } \\
\text { CTA AAC TGA ATG GGT GAA AC }\end{array}$ & $\begin{array}{l}94^{\circ} \mathrm{C} 1 \mathrm{~min} \\
54^{\circ} \mathrm{C} 1 \mathrm{~min} \\
72^{\circ} \mathrm{C} 1 \mathrm{~min}\end{array}$ & 942-bp & $\begin{array}{l}\text { AluI } \\
\text { SmlI }\end{array}$ & $\begin{array}{l}\text { Shuiep } \\
\text { et al.(2013) }\end{array}$ \\
\hline
\end{tabular}

\begin{tabular}{|c|c|c|c|c|}
\hline Le & c & 1 & CACAAגGATGACTCTGCTATCGTCAAATCTTPCCTITTGTCATCTICCTATT & co \\
\hline $2.11=10$ & $\mathbf{r}$ & 1 & CACAAAGATGACTCTCCTATCGTCAAATCTITCCTITITGTCATCTICCTATTGGGTGIA & $\mathrm{co}$ \\
\hline $2.1=1 e$ & a & 61 & 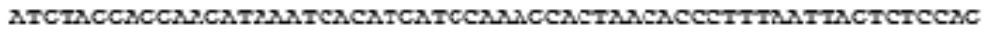 & 120 \\
\hline A.11ele & ᄂ & G1 & ATGTAGGAGGAAGATAAATCACATGATECAAAGCACTAACACCCTITAATIAGTCTCCAG & \\
\hline $\begin{array}{l}2.1=10 \\
211.10\end{array}$ & $\underline{\mathbf{L}}$ & $\begin{array}{l}121 \\
121\end{array}$ & 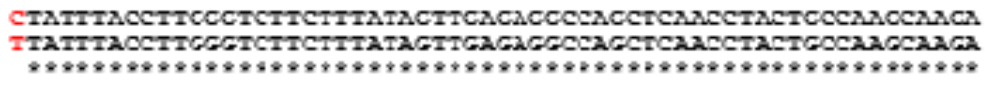 & \\
\hline $\begin{array}{l}211.10 \\
211=1 \%\end{array}$ & $\bar{T}$ & $\begin{array}{l}181 \\
181\end{array}$ & 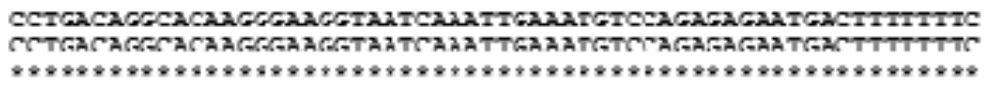 & \\
\hline $\begin{array}{l}\text { A.1Ele } \\
\text { A1 } 1=1 \text { r }\end{array}$ & 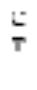 & 241 & 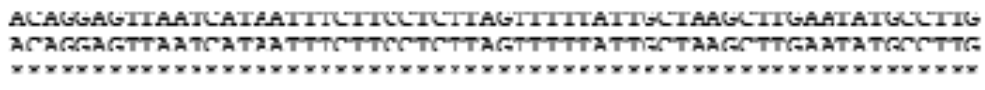 & \\
\hline $\begin{array}{l}\text { Allele } \\
\text { Allele }\end{array}$ & $\underline{I}$ & $\begin{array}{l}301 \\
301\end{array}$ & 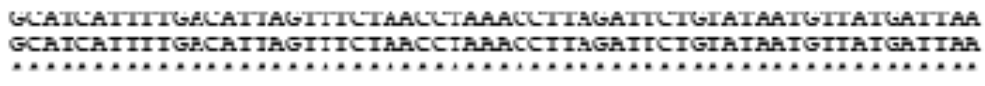 & \\
\hline $\begin{array}{l}\text { Allele } \\
\operatorname{Mil}=1 \mathrm{e}\end{array}$ & $\begin{array}{l}= \\
r\end{array}$ & $\begin{array}{l}301 \\
301\end{array}$ & 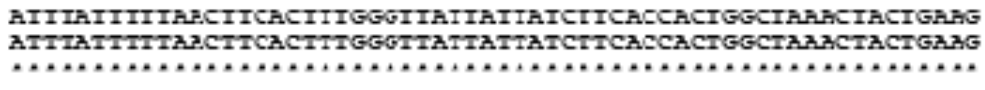 & \\
\hline A.11=1e & c & 421 & 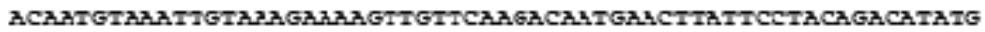 & \\
\hline $2.11=10$ & $\mathbf{r}$ & 421 & ACAMTGTARATTGTAMAGAMAAGTTGTTCAAGACAMTGAMCTTATTCCTACAGACATATG & \\
\hline 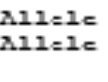 & $\begin{array}{l}\mathrm{c} \\
\mathrm{r}\end{array}$ & $\begin{array}{l}181 \\
181\end{array}$ & $\begin{array}{ll}\operatorname{rCCNCCCC} & 1 \varepsilon 8 \\
\operatorname{TCC} 2 C C C C & 1 \varepsilon 8 \\
* * * * * * * & \end{array}$ & \\
\hline
\end{tabular}

Fig. 1. The sequence alignment between two different Allele $\mathrm{C}$ and Allele T using ClustalW2 
The total protein contents of camel's milk ranged from $2.4 \%$ to $5.3 \%$ (Konuspayeva et al., 2009; Al haj \& Al Kanhal, 2011; Nikkah, 2011) and it is divided into casein and whey proteins. The casein fraction constitutes $52 \%$ to $89 \%$ of total camel milk protein and it divided into 4 fractions namely $\alpha$ s1, $\alpha$ s2, $\beta$ and k-caseins which encoded by four tightly genes (Kappeler et al., 1998).

In spite of the important role of casein genes and the effects of their genetic polymorphisms on quantitative traits and
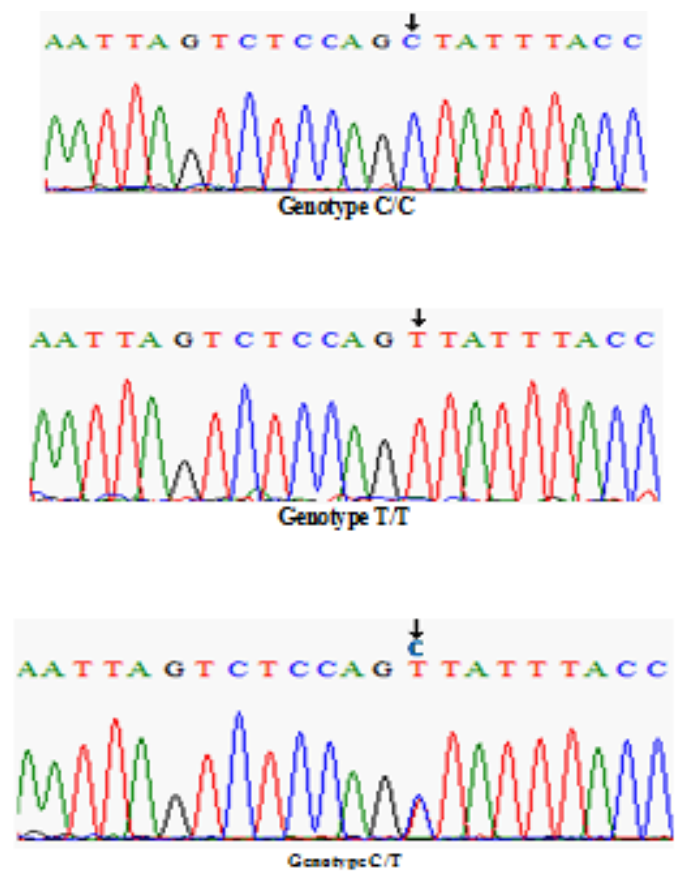

Fig. 2. The SNP $(\mathrm{C} \rightarrow \mathrm{T})$ in the three detected different genotypes technological properties of milk, the studies for the detection of genetic polymorphism of camel milk genes are still limited. Due to this fact, this work focused - using PCR-RFLP and sequencing on the identification of genetic polymorphisms of two casein genes in Maghrabi camel breed which is a dual purpose camel breed in Egypt.

\section{$\mathrm{\text {-caseingene }}$}

$\kappa$-casein $(\kappa-\mathrm{CN})$ is highly heterogeneous, soluble in the presence of calcium and differs considerably in structure from the calcium sensitive caseins (Fox \& McSweeny, 2003). Kappa casein is essential for micelle formation and stabilization, so it influences the manufacturing properties of milk. Cheese making is based on the cleavage of the $\kappa$ CN Phenylalnine ${ }^{105}$-Methionine ${ }^{106}$ peptide bond by enzymes or heat (Yahyaoui et al., 2001). The $\kappa-\mathrm{CN}$ fraction constitutes 3.5\% of total caseins in camel milk (El Agamy, 2006). Five different isoforms of $\kappa-$ CN were found in camel milk due to a strong glycosilation of this protein. Genetic variations at DNA level of $\kappa$-casein in Somali camels did not showed any polymorphism (Kappeler et al., 1998). Due to the rare results in this field, our study aimed to detect the genetic polymorphism in exon 1 of $\kappa$ casein gene in Maghrabi came reared in Egypt.

The primers used in this study amplified 488-bp fragments (Pauciullo et al., 2013) which spans from -137 bp of 5'-flanking region to +351 bp of the camel $\kappa$-CN gene. The amplified fragments were digested with two different restriction enzymes; SmII and AluI. The results of SmlI digestion did not showed any differentiation between tested animals where there is no any restriction site for this endonuclease in the amplified fragments. Regarding to AluI, the results

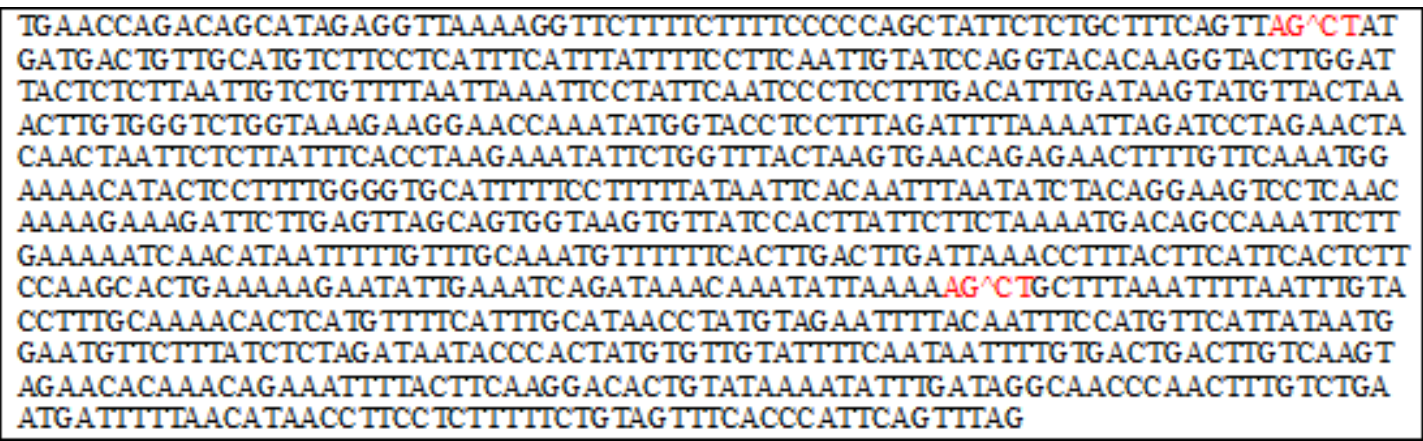

Fig. 3. The nucleotide sequence of 942-bp amplified fragment of ás1-casein gene $\mathrm{AG}^{\wedge} \mathrm{CT}$ restriction sits at positions $68^{\wedge} 69$ and $631^{\wedge} 632$ in red 
$\downarrow$

GT TAGCTATG ATG ACTG T TGCATG TC
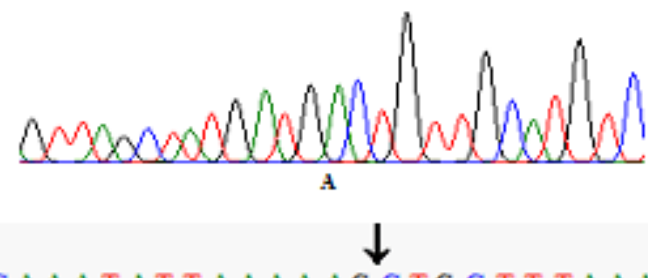

CAAATATAAAAG CTG C T TAAA

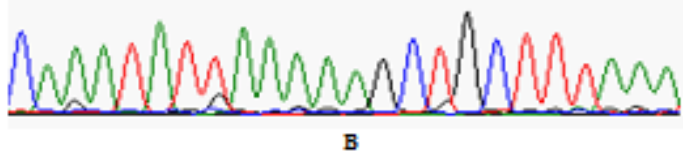

Fig. 4. The sequences analysis showed two restriction sites $\mathrm{AG}^{\wedge} \mathrm{CT}$. A (68^69) and B (631^632) showed the appearance of three different genotypes in the tested animals; CC with four digested fragments at 203-, 127-, 120- and 38-bp, TT with three digested fragments at 203-, 158- and 127-bp and CT with five digested fragments at 203-, 158-,
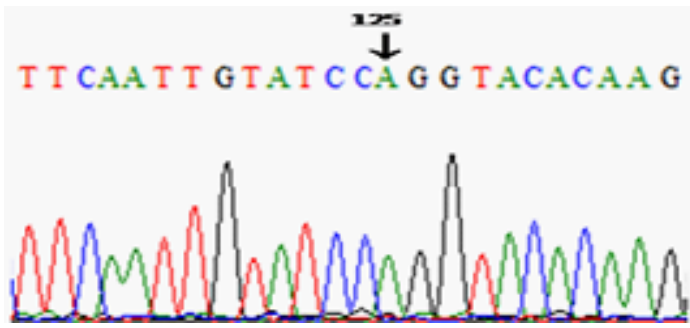

Fig. 5. The sequence analysis of Maghrabi camel as1-casein gene showed A nucleotide at position 125

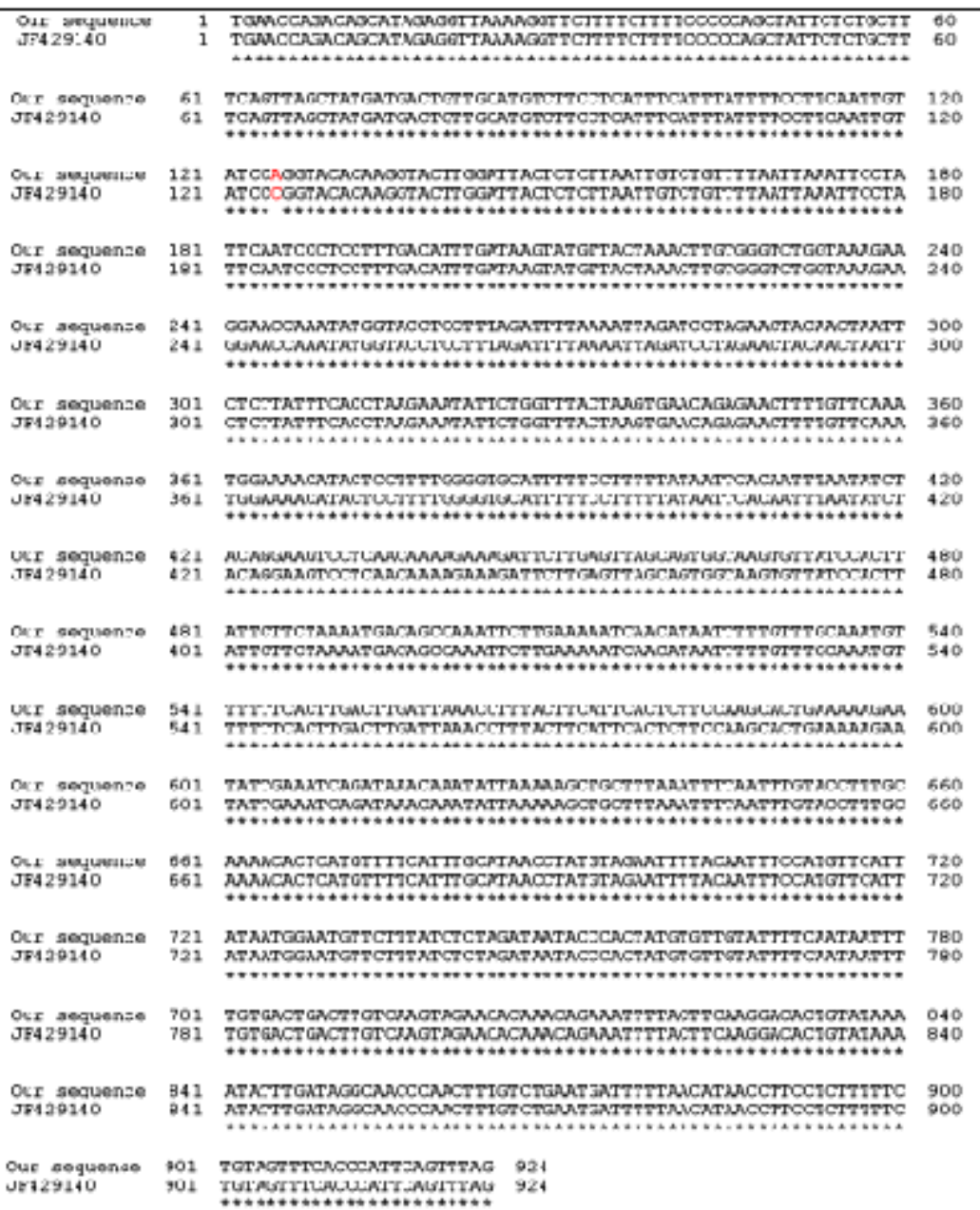

Fig. 6. Fig. 6. The sequence alignment of Maghrabi as1-Casein gene with the published sequence. $\mathrm{A} \rightarrow \mathrm{C}$ substitution at position 125 in red 
127-, 120- and 38-bp.

The representative samples for each detected genotype were sequenced and the results declared the presence of a single nucleotide polymorphism $(\mathrm{C} \rightarrow \mathrm{T})$ at position 121 in the amplified fragments which is responsible for the destruction of restriction site (AG/CT) at this position in allele $\mathrm{T}$ and resulted in the presence of two different alleles C (32\%) and T (68\%) (Fig. 1) with three different genotypes CC (12\%), CT (40\%) and CT (48\%) (Fig. 2). The nucleotide sequences of $\kappa$-CN alleles $\mathrm{C}$ and $\mathrm{T}$ were submitted to GenBank with the accession numbers; KU055605 and KU055606, respectively.

Pauciullo et al. (2013) reported the same SNPT $>C$ in exon 1 of C. dromedaries k-CN after the digestion of amplified fragment with AluI restriction enzyme in four Sudanese breeds. They detected three different genotypes; CC (18.09\%), TT (42.55\%) and CT (39.36\%). This finding agrees with our results where the genotype TT has the highest frequency followed by CT genotype and finally the CC genotype with the lowest frequency.

Kappa-casein gene polymorphism and its association with milk production traits was identified in cattle (Gouda et al., 2013; Deb et al., 2014), buffalo (Otaviano et al., 2005; Othman, 2005; Abbasi et al., 2009), sheep (Yousefi et al., 2013; Othman et al., 2013a) and goat (Kiplagat et al., 2010; Jemmali, et al., 2013).

as1-casein gene:

$\alpha$ s1-casein ( $\alpha$ s1-CN) is a structural component of the casein micelle, and plays an essential role in cheese curd formation (Walstra et al., 1984). as1-CN constitutes the second fraction of camel milk protein after $\kappa$-casein. This casein gene showed different genetic variations in ruminants depending on the presence of deletions or substitutions in the triple code of amino acids (Clement et al., 2006; Chessa et al., 2010). as1casein polymorphism affect the milk lipids and proteins compositions, so it has a strong impact on nutritional quality and technological properties of milk (Ollier et al., 2008).The present study examined the genetic polymorphism of as1-casein gene in Maghrabi came reared in Egypt. The primers used in this study amplified 942-bp fragments spanning from exon 4 to exon 6 (Shuiep et al., 2013).

The amplified fragments were digested with two different restriction enzymes; SmII and
AluI. The results of SmlI digestion did not showed any restriction site whereas the digestion with AluI endonuclease revealed the presence of two restriction sites $\mathrm{AG}^{\wedge} \mathrm{CT}$ at positions $68^{\wedge} 69$ and $631^{\wedge} 632$ (Figs. 3 and 4) yielding the presence of three digested fragments with sizes 68-, 563- and 293-bp.

The sequence alignment of as1-casein gene in Maghrabi camel with the published sequence (Accession No.: JF429140) declared the similarity at $99 \%$ with only one SNP $(A \rightarrow C)$ at position 125 (Figs 5 and $\mathbf{6}$ )

Molecular characterization of ás1-casein gene was studied in Sudanese camels PCR-RFLP by Shuiep et al. (2013). They reported a SNP $(G \rightarrow T)$ characterized for the new variant CSN1S1C of this gene where this SNP destroyed the restriction site of SmlI. This finding matches with our result where the amplified fragments of Maghrabi camels did not digested with this enzyme.

The molecular characterization and the association between $\alpha$ s1-casein polymorphisms with milk performance were studied in ruminants like cattle (Kishore et al., 2013; Shahlla et al., 2014), buffalo (El Nahas et al., 2013; Patel et al., 2014), sheep (Othman et al., 2013b; Ceriotti et al., 2013), goat (Soares et al., 2009; Jemmali et al., 2012).

In conclusion, the detection of genetic polymorphism and DNA sequencing of QTL genes especially milk composition is considered the best way for enhancing milk production and composition through the selection of animal with superior traits depending on molecular markers (MAS). Due to the economically important of camel in dry and semidry region in the world, further studies on genetic polymorphism of camel milk protein genes and its association with milk traits are needed in the future for genetic improvement of camel milk production.

\section{REFERENCES}

1. Abbasi, A., Fayazi, J., BeigiNasiri, M.T., Roshanfekr, H.A., Mirzadeh, K., Sadr, A.S. Analysis of kappa casein gene polymorphism by PCR-RFLP in buffalo population in Khouzestan Province. Res. J. Biol. Sci., 2009; 4(10): 1073-2009

2. Al-haj, O.A., Kanhal, A.I. Compositional, technological and nutritional aspects of dromedary camel milk. Int. Dairy J., 2011; 20: 
811-821

3. Bastos, E., Cravador, A., Azevedo, J., GuedesPinto, H. Single strand conformation polymorphism (SSCP) detection in six genes in Portuguese indigenous sheep breed "Churra da Terra Quente”. Biotechnol. Agron. Soc. Environ., 2001; 5: 7-15.

4. Ceriotti, G., Chessa, S., Bolla, P., Budelli, E., Bianchi, L., Duranti, E., Caroli, A. Single nucleotide polymorphisms in the Ovine casein genes detected by polymerase chain reactionsingle strand conformation polymorphism. $J$. Dairy Sci., . 2004; 87(8): 2606-2613.

5. Chessa, S., Rignanese, D., Berbenni, M., Ceriotti, G., Martini, M., Pagnacco, G., Caroli, A. New genetic polymorphisms within $\beta$ - and aS2-caseins. Small Rumin. Res., 2010; 88: 8488

6. Clement, P., Agboola, S., Bencini, R. A study of polymorphism in milk proteins from local and imported dairy sheep in Australia by capillary electrophoresis. LWT-Food Sci. Technol., 2006; 39: 63-69.

7. Deb, R., Singh, U., Kumar, S., Singh, R., Sengar, G., Sharma, A. Genetic polymorphism and association of kappa-casein gene with milk production traits among Frieswal $(\mathrm{HF} \times$ Sahiwal)cross breed of Indian origin. Indian $J$. Vet. Res., 2014; 15(4): 406-408

8. El Agamy, E.I. Camel milk. In: Handbook of non-bovine mammals. Iowa, NJ, USA: Blackwell Publisher Professional, 2006; pp: 297-344.

9. El Nahas, S.M., Bibars, M.A., Taha, D.A., ElSayyad, H.I. Detection of two CSN1S1 variants in Egyptian buffalo. J., Genet. Eng. Biotech., 2013; 11: 75-77.

10. El-Sawalhy, A.A., Montaser, A.M., Rizk, L.G. Diagnostic and biochemical evaluation of camel brucellosis. Vet. Med. J., 1996; 44: 323-329

11. Fox, P.F., McSweeny, P.L.H. Advanced diary chemistry, volume 1 proteins ( $3^{\text {rd }}$ edition, part A), Klumer Acadimic, plenium publishers. New York, USA., 2003; pp: 286- 289

12. Ge, W., Davis, M.E., Hines, H.C., Irvin, K.M., Simmen, R.C.M. Association of single nucleotide polymorphisms in the growth hormone and growth hormone receptor genes with blood serum insulin-like growth factor I concentration and growth traits in Angus cattle. J. Anim. Sci., 2003; 81: 641-648.

13. Gouda, E.M., Galal, M.Kh., Abdelaziz, S.A. Genetic variants and allele frequencies of kappa casein in Egyptian cattle and buffalo using PCRRFLP. J. Agric. Sci., 2013; 5(2): 197-203.

14. Gupta, N., Ahlawat, S.P.S., Kumar, D., Malik, G. Single nucleotide polymorphism in growth hormone gene exon-4 and exon-5 using PCRSSCP in Black Bengal goats - A prolific meat breed of India. Meat Sci., 2007; 76: 658-665

15. Jemmali, B., Kamoun, M., Haddar, M., Ben Gara, A., Selmi, H., Hammami, M., Amraoui, M., Rouissi, H., Boulbaba, R. Genetic polymorphism of casein alpha-S1 gene in Tunisian local goat. Biomirror., 2012; 3(11): 4851.

16. Jemmali, B., Ben Gara, A., Selmi, H., Ammari, Z., Bouheni, C., Ben Larbi, M., Hammami, M., Amraoui, M., Kamoun, M., Rouissi, H., Rekik, B. Kappa casein gene polymorphism in local Tunisian goats. Pakistan J. Biol. Sci., 2013; 16: 2031-2035.

17. Kappeler, S., Farah, Z., Puhan, Z. Sequence analysis of Camelus dromedarius milk caseins. J. Dairy Res., 1998; 65: 209-222

18. Kishore, A., Mukesh, M., Sobti, R.C., Mishra, B.P., Sodhi, M. Variations in the regulatory region of alpha S1-casein milk protein gene among tropically adapted Indian native (Bos Indicus) cattle, 2013; http://dx.doi.org/10.5402/ 2013/926025

19. Kiplagat, S.K., Agaba, M., Kosgey, I.S., Okeyo, M., Indetie, D., Hanotte, O., Limo, M.K. Genetic polymorphism of kappa-casein gene in indigenous Eastern Africa goat populations. Int. J. Genet. Mol. Biol., 2010; 2(1): 1-5.

20. Konuspayeva, G., Faye, B., Loiseau, G. The composition of camel milk: a meta-analysis of the literature data. J. Food Comp. Anal., 2009; 22: 95-101.

21. Lucy, M.H., Hauser, S.D., Eppard, P.J., Krivi, G.G., Collier, R.J. Genetic polymorphism within the bovine somatotropin (bST) gene detected by polymerase chain reaction and endonuclease digestion. J. Dairy Sci., 1991; 74 (Suppl. 1), 284

22. Mahran, O.M.. Some studies on blood parasites in camels (Camelus dromedarius) at Shalateen city, Red Sea Governorate. Assuit Vet. Med. J., 2004; 50(102): 172-184.

23. Mehari, Y., Mekuriaw, Z., Gebru, G. Potentials of camel production in Babilie and Kebribeyahworedas of the Jijiga Zone, Somali Region, Ethiopia. Livestock Res. for Rural Develop., 2007; 19: 4-7.

24. Miller, S.A., Dykes, D.D., Polesky, H.F. A simple salting out procedure for extracting DNA from human nucleated cells. Nucleic Acids Res., 1988; 16: 1215.

25. Nikkah, A. Equidae, camel, and yak milks as functional foods: a review. J. Nut. Food Sci., 2011; 100-111.

26. Ollier, S., Chauvet, S., Martin, P., Chilliard, Y., Leroux, C. Goat's $\alpha_{\mathrm{S} 1}$-casein polymorphism 
affects gene expression profile of lactating mammary gland. Animal, 2008; 2(4): 566-573

27. Otaviano, A.R., Tonhati, H., Sena, J.A.D., Munoz, M.F.C. Kappa-casein gene study with molecular markers in female buffaloes (Bubalus bubalis). Genet. Mol. Biol., 2005; 28(2): 237241.

28. Othman, E.O. The identification of kappa-casein genotyping in Egyptian river buffalo using PCRRFLP. Arab J. Biotech., 2005; 8(2): 265-274.

29. Othman, E.O., Samia, A.E., Nagwa, A.H, Eman, R.M., Esraa, A.B. Genetic variations of b- and k-casein genes in Egyptian sheep breeds. J. Appl. Biosci., 2013a; 64: 4858-4866.

30. Othman E.O., Samia A.E., Nagwa A.H., Eman R.M., Esraa A. B. Genetic polymorphism detection of two alpha-casein genes in three Egyptian sheep breeds. J. Genet. Eng. Biotech., 2013b; 11(2): 129-134.

31. Patel, A.K., Singh, M., Suryanarayana, V.V.S. Buffalo alpha S1-casein gene 5 '-flanking region and its interspecies comparison. J. Appl. Genet., 2014; 55(1): 75-87.

32. Pauciullo, A., Shuiep, E.S., Cosenza, G., Ramunno, L., Erhardt, G. Molecular characterization and genetic variability at êcasein gene (CSN3) in camels. Gene., 2013; 513(1): 22-30

33. Provot, C., Persuy M.A., Mercier, J.C. Complete sequence of the ovine â-casein encoding gene and interspecies comparison. Gene., 1995; 154: 259-263.

34. Ramunno, L., Cosenza, G., Pappalardo, M., Pastore, N., Gallo, D., Di Gregorio, P., Masina, P. Identification of the goat CSN1S1 F allele by means of PCR-RFLP method. Anim. Genet., 2000; 31: 333-346

35. Schlee, P., Graml, R., Rottmann, O., Pirchner, F. Influence of growth hormone genotypes on breeding values of Simmental bulls. J. Anim.
Breed. Genet., 1994; 111: 253-256.

36. Shahlla, N., Ullah, O., Sheikh, R. Genetic polymorphism of milk protein variants and their association studies with milk yield in Sahiwal cattle. African J Biotech., 2014; 13(4): 555-565.

37. Shuiep, E.S., Giambra, I., El Zubeir, I.M., Erhardt, G. Biochemical and molecular characterization of polymorphisms of á -casein in Sudanese camel (Camelus dromedarius) milk. Int. Dairy J., 2013; 28(2): 88-93.

38. Soares, M.A.M., Rodrigues, M.T., Mognol, G.P., Ribeiro, L.F.C., Silva, J.L.C., Brancalhão, R.M.C. Polymorphism of alpha s1-casein gene in a dairy goat herd in the southeastern region of Brazil. R. Bras. Zootec., 2009; 38(6): 1026-1032.

39. Sodhi, M., Mukesh, M., Prakash, B., Mishra, B.P., Sobti, R.C., Karn Singh, P., Singh, S., Ahlawat, S.P.S. MspI allelic pattern of bovine growth hormone gene in Indian Zebu cattle (Bos indicus) breeds. Biochem. Genet., 2007; 45: 145153.

40. Swaisgood, H.E., Chemistry of the caseins. In Advanced Dairy Chemistry, 1. Proteins. (Ed. P. F. Fox). London. 1992; pp. 63-110

41. Wallis, M., Lioupis, A., Wallis, O.C. Duplicate growth hormone genes in sheep and goat. J. Mol. Endocrin., 1998; 21: 1-5.

42. Walstra, P., Jenness, R., Badings, H.T. Dairy Chemistry and Physics. Wiley, New York, 1984; pp. 467

43. Yahyaoui, M.H., Coll, A., Sanchez, A., Josep, M., Folch, J.M. Genetic polymorphism of the caprine kappa casein gene. Appl. Sci. J. Dairy Res., 2001; 68: 209-216.

44. Yousefi, S., Azari, M.A., Zerehdaran, S., Samiee, R., Khataminejhad, R. Effect of $\beta$-lactoglobulin and $\hat{\text { e}}$-casein genes polymorphism on milk composition in indigenous Zel sheep. Archiv.Tierzucht., 2013; 56(21): 216 -224. 